\title{
Between Pragmatism and Realism
}

The Philosophy of John Elof Boodin

\section{Matthias Neuber}

\section{(2) OpenEdition \\ 1 Journals}

Electronic version

URL: http://journals.openedition.org/ejpap/1547

DOI: $10.4000 /$ ejpap. 1547

ISSN: 2036-4091

\section{Publisher}

Associazione Pragma

\section{Electronic reference}

Matthias Neuber, "Between Pragmatism and Realism », European Journal of Pragmatism and American Philosophy [Online], XI-1 | 2019, Online since 19 July 2019, connection on 21 July 2019. URL : http://journals.openedition.org/ejpap/1547 ; DOI : 10.4000/ejpap.1547

This text was automatically generated on 21 July 2019

\section{(c) $(1)$}

Author retains copyright and grants the European Journal of Pragmatism and American Philosophy right of first publication with the work simultaneously licensed under a Creative Commons AttributionNonCommercial-NoDerivatives 4.0 International License. 


\title{
Between Pragmatism and Realism
}

The Philosophy of John Elof Boodin

\author{
Matthias Neuber
}

\section{Introduction}

1 The present paper is devoted to a systematic reconstruction of the philosophical approach of the Swedish-born thinker John Elof Boodin (1869-1950). It will be shown that Boodin's work underwent a development from a more or less direct form of pragmatism to a certain variant of realism, which Boodin himself called "functional" realism. In order to adequately understand this shift in philosophical perspective, it is important to take into account both Boodin's intellectual socialization in the United States and the surrounding philosophical context. Thus, in section 2 of this paper, I shall provide some information concerning Boodin's life and work, and, in section 3, I shall reflect on the philosophical situation in the United States during the first two decades of the twentieth century. Section 4 discusses Boodin's specific understanding, blending and eventual disentanglement of pragmatist and realist ideas. Section 5 concludes the paper with some critical comments.

\section{Boodin's Life and Work ${ }^{1}$}

John Elof Boodin was born in Pjätteryd, Småland (Southern Sweden), in 1869. Being one of nineteen children of a farmers family (his father had married twice), he, at the age of 18 , decided (like a couple of his siblings) to emigrate to the United States. Boodin knew no English when he arrived in Colchester, Illinois, in 1887. And he had no money. However, one of his brothers had settled in Colchester some time before. Moreover, the little town housed around one hundred Swedish immigrants, which in turn helped Boodin to work for the Episcopal Church during the first few years. After a short time working in a "low vein" mine owned by the Quincy Coal Company, Boodin attended Augustana College in Rock Island, Illinois, in 1890-91 where he studied Latin, Greek, Swedish, and Geometry. In 1893, he got a position as a lay reader in the Episcopal Church of St. Mark in Minneapolis, 
Minnesota, where he did parish work with other Swedish immigrants. Boodin transferred his college studies to the University of Minnesota and made acquaintance with the work of William James. Being fascinated by the latter's academic contributions Boodin became eager to study under James at Harvard. This plan didn't work out, but Boodin received a funded scholarship at nearby Brown University. There he studied philosophy and received his master's degree in 1896. In 1896-97, he taught Logic, Ethics, and Comparative Religion at Brown. Furthermore, he participated in the department Philosophy Club. As a matter of fact, it was in this context that he personally encountered James for the first time. At one of the Philosophy Club's meetings, James gave a talk titled "Is Life Worth Living?". Boodin attended the talk. And he did not remain unrecognized. As Nelson points out in his biographical sketch:

Though Boodin was awed by James - the very man he had most wanted to meet - he proceeded during the discussion period to ridicule some of the points James had made. [...] [H]is critical speech had made a permanent impression. James inquired into Boodin's background and plans, and nicknamed him "the orator." He then went on to revise his paper in response to Boodin's critique. He presented the new version at a subsequent meeting of the Brown Philosophy Club that year. (Nelson 1984: 137)

3 In 1897, Boodin eventually entered Harvard (on a Hopkins scholarship). There, he primarily studied with the American idealist Josiah Royce and came in closer (friendshiplike) contact with James. At that time, Harvard no doubt was the stronghold of (the still quite young) American philosophy. Among Boodin's fellow graduate students were the later influential realist philosophers Arthur O. Lovejoy, William Pepperell Montague, Edwin B. Holt, and Ralph Barton Perry. In 1899, Boodin finished his dissertation on "The Concept of Time."

After his stay at Harvard, Boodin had a couple of academic positions in the United States, culminating with his becoming Faculty Research Lecturer at U.C.L.A. in 1937. In the same year, he was elected to membership in the permanent council of the World Congress of Philosophy. In 1932-33 he had already served as president of the American Philosophical Association, Western Division. Boodin died in 1950.

5 As for Boodin's philosophical work, it should be mentioned first that he is characterized by Shook as one of the twelve "major figures" (Shook 1998: xiii) of pragmatism. Boodin himself writes at one place: "Whether I had any influence in turning pragmatism into a more realistic direction, I do not know." (Boodin 1930: 140). Be that as it may, the particularly realistic element in Boodin's approach to pragmatism had obviously to do with his European, Swedish, roots. According to Pihlström, Boodin was of the opinion "that his work and training on his home farm with intimate contact with nature may have made him an 'empirical realist"' (Pihlström 2010: 6). At any rate, the emigration to the United States fundamentally changed Boodin's overall outlook. Thus one can read in his book The Social Mind from 1939:

I was uprooted from my community. However kind the new world has been and whatever my success within it, the loss of my own community has always haunted me. The change meant a change of language, a change of history and tradition. It was a complete cleavage with my world before eighteen. (Boodin 1939: 56)

6 Whether Boodin's specific variant of philosophical thinking should be seen as an expression of "European pragmatism" is hard to say. Maybe his Swedish rural growing up, as it were, predestined him in terms of viewing the world from a primarily realistic point of view. On the other hand, it should be seen that his entire academic education 
took place in the United States. And it is more than obvious that his principal inspirations were promoted by his tight academic contacts with James and Royce at Harvard. Moreover, his Harvard student fellows, such as Holt, Montague or Perry, attempted to interpret James's account of pragmatism within a realistic framework. ${ }^{2}$ Accordingly, a fusion of pragmatism and realism seemed to be en vogue among the younger Harvard generation. Boodin himself belonged to that very generation, so that it appears more adequate to speak of the "pragmatism of a European-born philosopher" than of Boodin's "European pragmatism."

7 Boodin published eight books and more than sixty articles for journals, both in the field of theoretical philosophy (which concerns us here) and in the field of practical philosophy. His major contributions to theoretical philosophy are the following: the 1911 book Truth and Reality; the 1916 book A Realistic Universe; and an article published in 1934 (in The Philosophical Review) titled "Functional Realism." In Truth and Reality, Boodin explicitly argues for what he calls "pragmatic realism" (see Boodin 1911a, esp. ch. XIV). Interestingly enough, the dedication of that book reads as follows: "To my friend and teacher William James, not the late but the ever living and inspiring genius of American philosophy, this book is affectionately dedicated." The five years later published Realistic Universe, then, is dedicated to "my friend and teacher Josiah Royce." In programmatic terms, Boodin argues in that book for what he now calls "pragmatic energism" (see Boodin 1916, esp. ch. III). Whereas Truth and Reality is, according to its subtitle, an "Introduction to the Theory of Knowledge," A Realistic Universe is, according to its subtitle, an "Introduction to Metaphysics." Boodin's 1934 "Functional Realism" doesn't contain any mentioning of pragmatism or pragmatic elements. We will see later why.

On the whole, Boodin's philosophical work fell into oblivion with the death of its author. Even during his lifetime, Boodin had the impression that his philosophical contributions were not sufficiently appreciated. According to Nelson, "Boodin lived in the continual hope that times would change and that people would increasingly look to his work [...] as a source of sanity, value, and enlightenment. It was the greatest disappointment of his life that this did not happen." (Nelson 1984: 145).

\section{The Philosophical Context}

Before discussing the details and the development of Boodin's philosophical position, it is instructive to take a brief look at the surrounding philosophical context. Regarding the situation in late nineteenth-century American philosophy, it can be said that idealism, especially in the form advocated by Royce, was the prevailing point of view. ${ }^{4}$ Royce's Gifford Lectures, delivered at the University of Aberdeen in two series in 1899 and 1900, proved to be particularly impactful. In Royce's opinion, there is no way out of our "absolute system of ideas." Reality itself is an idea, and it is for this reason that Royce, quite frankly, states: "[W]e propose to answer the question: What is to be? by the assertion that: To be means simply to express, to embody the complete internal meaning of a certain absolute system of ideas, - a system, moreover, which is genuinely implied in the true internal meaning of purpose of every finite idea, however fragmentary." (Royce 1900, 36).

It can hardly surprise that statements like these provoked a realist reaction. And indeed, it were (among others) some of Royce's best students who stood at the forefront of a new 
movement in early twentieth-century American philosophy. Inspired by James's "Does Consciousness Exist?" (1904), authors such as Holt, Montague, and Perry had joined forces, in order to promote what they called "new" realism. ${ }^{5}$ The attribute "new" had partially to do with the fact that the members of that group saw themselves as participating to the new scientific endeavor (informed by both psychology and the natural sciences) which demanded a more robust realist epistemology. Their most outstanding contribution was the cooperative volume The New Realism, which appeared in 1912. But already two years earlier they had published "The Program and First Platform of Six Realists." In this manifesto, they came along with a couple of - more or less general - realist theses. Holt, for example, claimed that "[t]he entities [...] under study in logic, mathematics, and the physical sciences are not mental in any usual or proper meaning of the word "mental"' (Holt in Holt et al. 1910: 394). Going in the very same direction, Montague stated that "the existence of a thing is not correlated with or dependent upon the fact that anybody experiences it, perceives it, conceives it, or is in any way aware of it" (Montague in Holt et al. 1910: 396). Edward Gleason Spaulding, another of the new realists, even went as far as to assert that consciousness and the process of knowing as such are "eliminable" (Spaulding in Holt et al. 1910: 399).

11 In a similar vein, American pragmatism had evolved as an anti-idealistic movement. James's "Does Consciousness Exist?" is a good example in this respect. Also his seminal lecture series Pragmatism from 1907 and especially his 1909 monograph A Pluralistic Universe should be seen under this aspect. ${ }^{6}$ However, it was John Dewey who most firmly stressed the realistic element in pragmatism. Thus in an article from 1905, titled "The Realism of Pragmatism," Dewey points out:

Speaking of the matter only for myself, the presuppositions and tendencies of pragmatism are distinctly realistic; not idealistic in any sense in which idealism connotes or is connoted by the theory of knowledge. [...] Pragmatism believes that in knowledge as a fact, an accomplished matter, things are "representative of another." Ideas, sensations, mental states are, in their cognitive significance, media of so adjusting things to one another that they become representative of one another. When this is accomplished, they drop out; and things are present to the agent in the most naïvely realistic fashion. (Dewey 1905: 324-5)

It is a well-known fact that, in the further course of the twentieth century, pragmatism became the predominant philosophical current in the United States (cf. Misak 2013). Its accentuation of practice and consequences appeared as something "distinctively American" (Sellars 1969: 27). Yet, the philosophical scenario in the 1910s and 1920s was quite complex. Besides idealism, neo-realism, and pragmatism there existed a further influential movement, namely so-called critical realism. The critical realists philosophers such as Durant Drake, George Santayana, Roy Wood Sellars and the already mentioned Arthur 0. Lovejoy - shared the neo-realists' rejection of idealism. Moreover, the critical realist movement joined in the format of cooperative publication as already executed by the new realists' 1912 volume. Thus in 1920 they published their Essays in Critical Realism, which was subtitled "A Cooperative Study of the Problem of Knowledge." In the preface to that volume, the authors pointed out:

The doctrine here defended, while definitely realistic, is distinctly different from the "new" realism of the American group, whose volume, published in 1912, was a signal example of the value of co-operative effort in crystallizing and advertising a point of view in philosophy. Our realism is not a physically monistic realism, or a merely logical realism, and escapes the many difficulties which have prevented the general acceptance of the "new" realism. (Drake et al. 1920: vi) 
As for the movement's label, the critical realists were critical insofar as they aimed at a more reflected approach to the issue of cognition (especially perception) than our everyday's "naïve" as well as philosophical "new" realism. ${ }^{8}$ They were realist insofar as they, on the other hand, agreed with new realism in the postulation of the existence of mind-independent things.

Regarding their relation to pragmatism, the critical realists no doubt saw certain affinities. As Sellars makes it clear in his Evolutionary Naturalism (1922), the critical realist "is very sympathetic with the position of the pragmatist, albeit he thinks that many pragmatists are too utilitarian and do not value enough, or sufficiently admit, a theoretical interest in knowledge" (Sellars 1922: 55-6). As Sellars further points out, critical realism is a "mediate" (77) position. "In it," Sellars writes, "both pragmatism of a chastened sort and neo-realism of a less doctrinaire type may ultimately find the satisfaction of their insights." (Ibid.). However, the prevailing attitude toward pragmatism in the critical realist camp was unfavorable. This becomes particularly clear from Lovejoy's contribution to the 1920 essay volume. Titled "Pragmatism Versus the Pragmatist," Lovejoy's paper may be considered as one of the most unrelenting critiques of the pragmatist point of view. In his opinion, "the doctrine commonly put forward as 'pragmatism' may be said to be a changeling, substituted almost in the cradle" (Lovejoy 1920: 80). ${ }^{9}$

15 Summing up thus far, it can be stated that Boodin, when he entered the American philosophical scene, encountered a confusing, if not chaotic, diversity of programs, movements and related -isms. Our next task will be to determine what he made out of this kind of situation.

\section{Boodin on the Relation between Pragmatism and Realism}

Boodin's chronologically first publication to be considered here is a paper titled "Philosophic Tolerance. A Winter Revery." It appeared in The Monist in 1908. Recall that James's Pragmatism had appeared in 1907. Boodin does not refer to James's lecture series in his paper, but he mentions the latter's "favorite principle of pragmatism" (Boodin 1908: 305). At the same time he speaks of "my friend Royce" (1908: 303), mentions the latter's "absolute idealism" (1908: 300$)$ and suggests that "[i]deals may prove truer than facts" (ibid.). It is apparent that Boodin seeks some sort of "idealized" as well as "humanized" conception of reality and truth. He explicitly analogizes philosophy and art. "Why," he asks, "should a man's soul be crowded into one system of philosophy?" (1908: 302). And he continues:

The ultimate realities with which metaphysics deals are no less plastic in the hands of the potter than the realities of art. In either case the soul is endeavoring to create an objective counterpart to its tendencies or needs, to mirror itself, become conscious of itself. Philosophy like poetry and art, when it is genuine, is only the expression of a mood of the soul, and it is not always for the artist to tell what mood is most significant. [...] In the realm of truth, as well as art, man must be the measure, however finite and passing the measure may be. (Ibid.)

17 James's conception of philosophy stands, according to Boodin, in that very tradition. Reflecting on his own philosophical development, especially on his time at Harvard, ${ }^{10}$ he provides the reader with the following picture: 
The temple where I spend most of my time is an unfinished Gothic sort of structure, where many artists are at work, each in his own way. I was introduced to the group by a friend of mine, the brilliant and human William James, who spent a lifetime trying to provide a framework and who is now at work on some plans for the interior. It is a place where everybody has something to do. Each one is allowed to choose his own task, make his own plan and fix his own salary. There is no supervision as yet, in fact the plan is that there shall be no supervision of the work as a whole. (Ibid.: 305)

Boodin is extremely enthusiastic about the prospects of this whole enterprise. He writes:

But after all, the center of interest in this religion is not the temple but the artists. The temple may never be finished, as each artist and each generation of artists modify the plans to suit their own ideals. But the artists get practice and the temple is first of all a school for artists. And each artist is paid at least through the joy of the working and the appreciation he feels for such momentary beauty as each can produce. Here at least the artist has the sense of doing something, for in the other temples there is nothing to do but contemplate that which is, whether beauty or desert. Here worship is work and work is worship. (Ibid.)

9 It was certainly this very passage that provoked the following critical comment by the journal's editors:

Pragmatism is the latest philosophical movement which is at present sweeping over the country, and the foregoing article by Professor Boodin may be taken as a typical instance of the philosophic temperament that is at present in the ascendancy. The founder of Pragmatism is Mr. Charles S. Peirce, and its standard bearer, Prof. William James of Harvard. We must confess that we do not share the enthusiasm of the pragmatism movement, and not join its ranks. We believe that it has its weak points, and it is our intention to publish in the coming number of The Monist a critical discussion of pragmatism as a system of philosophy. (Editorial Comment to Boodin 1908: 306)

As is well known, the Monist's editor-in-chief, German-born Paul Carus, stood in close contact to the pragmatists. Peirce, for example, published many of his most important papers for The Monist. However, Carus's own philosophical outlook was that of a Spinozist and a Buddhist (cf. Suzuki 1962). He believed in eternal truth and rejected its relativization by the pragmatists. ${ }^{11}$

21 The announced critical discussion of pragmatism as "a system of philosophy" can be found in Volume No. 15 of The Monist, published in 1909. Boodin, although invited to do so (see below, fn. 14), did not contribute to that volume. Instead, he published - in the very same year - an article titled "What Pragmatism Is and Is Not" for The Journal of Philosophy, Psychology and Scientific Method. He obviously knew of Peirce's 1905 contribution for The Monist (Peirce's paper had the title "What Pragmatism Is"). At any rate, Boodin starts his article with the following characterization:

In the first place, pragmatism as a doctrine is so simple and so old as a matter of scientific procedure that it is impossible to understand why so much dust should have been raised about it by its opponents. It is simply the application of the ordinary method of the scientific testing of an hypothesis to philosophic hypotheses as well. (Boodin 1909: 627)

As Boodin further makes it clear, the pragmatist holds that the truth of a hypothesis stands in close connection to human habit and conduct. "The truth of an idea or plan," he writes, "must be tested by the procedure to which it leads." (Ibid.). Accordingly, science, from the pragmatist point of view, is "a systematic sorting of experience in the realization of our interests" (ibid.: 629). 
23 All of this sounds pretty Jamesian. ${ }^{12}$ And the same holds true for the following passage (although it could likewise be read before the Peircean background):

Is pragmatism realistic? Only in so far as it intends a world beyond our finite cognitive purposes. The finite fragmentary intent must find its reality or correction in a larger whole. I do not know of any striving for truth which is not realistic in this sense. [...] The reality we seek to know may ultimately be more experience yes, we must be willing to have it turn out to be an absolute unity of thought, if the procedure of truth leads that way. (Ibid.: 632) ${ }^{13}$

On the whole, Boodin applauds the Jamesian variant of pragmatism. For him, as for James, truth, "so far as we are finite seekers are concerned, is a limit which we are far from having realized. Whether we can realize it or not only the historical outcome of the pragmatic test can prove." (Ibid.: 633).

In 1910, Boodin's paper "Pragmatic Realism" appeared in Volume No. 19 of The Monist. ${ }^{14}$ In that paper, Boodin again, and more explicitly, draws the connection between pragmatism and realism. Laying the focus on what is implied by a realistic - in contrast to an idealistic - point of view, he declares:

Leaving out all reference to the metaphysical stuff for the time being, realism means the reference to an object existing beyond the apperceptive unity of momentary individual consciousness, and that this object can make a difference to that consciousness so as to be known. The object, in other words, is dependent upon the cognitive moment not for its existence, but for its significance. Idealism, on the other hand, would hold that there is strictly only one unity of consciousness and that existence is a function of being part of a significant system. Thought is so wedded to things that things cannot exist without being thought. (Boodin 1910: 602-3)

It is clearly Royce's version of idealism to which Boodin is alluding in the last two sentences of that passage. Anyway, the actually important point is that by 'realism' he essentially understands an "epistemological attitude" (ibid.: 603) and not a "brand of metaphysics" (ibid.). Consequently, both idealism and materialism are, in his view, variants of "dogmatism" (ibid.: 606) and therefore to be abandoned. It is all but astonishing that Boodin continues thus:

Instead of the dogmatic method pursued by the old idealism and materialism alike, we must substitute scientific method. This method has been rechristened within recent years by C. S. Peirce and William James and called pragmatism. As I understand this method it means simply to carry the scientific spirit into metaphysics. (Ibid.: 608)

The Monist's editors (most probably Carus) laconically commented upon this claim by raising the following question: "If pragmatism avowedly accepts the scientific method, would it not be better to call it the "Philosophy of Science'?" (Editorial Comment to Boodin 1910: 614).

It was in Volume No. 21 of The Monist, published in 1911, that Boodin directly replied to that comment. He argued:

An hypothesis, whether of atoms or morals, God or devil, is true because it works. We do not wonder over the disappointment at this lack of novelty of the pragmatic method. No doubt Dr. Paul Carus expresses a general feeling when he says: "If pragmatism, as commonly understood, were truly nothing but another name for 'scientific method,' it would not have anything to offer." 15 But what the critic forgets is that pragmatism is the baptism of a new consciousness as to the meaning of science. It makes definite and articulate what was only implied before. Few great reformations have been original, to any great extent, in their intellectual content. 
Their originality has lain mostly in the simplicity and directness of their aim - the clearness and intensity of their emphasis. (Boodin 1911a: 85)

Apparently, pragmatism stood in need of being defended (or at least of being clarified) against its opponents.

In Truth and Reality, Boodin attempted to tackle this sort of challenge. In the preface to that book he made the following announcement:

In the bewildering amount of discussion and misunderstanding to which the pragmatic movement has led, there is need for fresh emphasis of the main issues. There is also need for building out the pragmatic theory in neglected directions. In a small way, this book tries to serve both purposes. (Boodin 1911b: vii)

Just as in "Pragmatic Realism" (which was included as chapter XIV in Truth and Reality), Boodin divorces himself from any metaphysical reading of the realist stance. This becomes obvious from his rejection of Kantian "things-in-themselves" (cf. Boodin 1911b: 58) as well as from his focusing on the pragmatic element in knowledge. He categorically distinguishes between "prediction and control of certain practical situations" (1911b: 60), on the one hand, and "nature in the abstract" (ibid.), on the other. However, James's theory of truth is, according to Boodin, only a halfway house. He points out:

While such a theory, with abundant illustrations from natural science, accounts for how knowledge can control the world of processes, it leaves us in the dark as to the real question - the relevancy of knowledge to its object. (Boodin 1911b: 216)

Boodin's own solution to that problem amounts to the endorsement of contemporary energetics, as it was primarily established in the German-speaking area by thinkers such as Wilhelm Ostwald and Georg Helm. ${ }^{16}$ On Boodin's reading, energetics provides us with the essential tools for bridging the gap between "the" subjective and "the" objective. In his own words:

Realism has always insisted upon the trans-subjective reference of the cognitive meaning. But the paradox, often pointed out by realists themselves, that the object must be both in and out of experience, must remain an absolute mystery so long as we deal with meanings as subjective pictures, inclosed within the magic circle of epiphenomenal consciousness. [...] If we, however, regard the universe under the conception of plural energetic centers, which can figure in various contexts, including our cognitive context, and some at least as having meaning of their own and capable of entering into cognitive relations with us; and if, furthermore, we regard cognitive purposes as themselves energies, evolving in complexity with, and having survival value through, their control of other energies, such as the physiological, then the paradox is resolved [...]. We have at least found a motive for our ideas seeking agreement with their intended reality, for successful adjustment in the end depends upon such agreement. And the only key to external reality is what we must take it as, in the realization of our purposes. (Boodin 1911b: 223-4)

Understood that way, the object itself becomes "a truth process" (ibid.: 225). The knower and the known are related through certain energetic dependencies. We will come back to this point in a moment. For the time being, it is important to note that, according to Boodin, any talk of truth requires some basis in the extra-mental realm. Consequently, the Jamesian reduction of truth to verification turns out to be insufficient. ${ }^{17}$

In the preface to his 1916 Realistic Universe, Boodin delivered a couple of programmatic clarifications. For one thing, he stressed that Truth and Reality and the present volume "furnish a survey of the field of general philosophy from the point of view of pragmatic realism" (Boodin 1916: vii). Whereas Truth and Reality belonged to the theory of knowledge, A Realistic Universe is, Boodin writes, "a volume on metaphysics" (ibid.). As 
concerns his primary sources of inspiration, he mentions James, Royce and "the vitalizing influence in our country of its great teacher, John Dewey, and the Chicago School" (1916: ix). On the other hand, he explicitly demarcates his position from "the movement sometimes called 'the new realism"' (ibid.). His own approach, Boodin maintains, "has little in common with it [i.e., new realism; M.N.] either in spirit or method" (1916: ix-x). Thus "pragmatic" realism should be seen as an independent variant within the realist camp.

Now Boodin's attitude in "Pragmatic Realism" was, as we have seen, non-metaphysical. In A Realistic Universe he changes this sort of attitude in favor of what might be called a scientifically informed account of metaphysics. In contrast to both idealism and materialism this kind of metaphysics is driven by criticism instead of dogmatism in terms of method. Writes Boodin:

For the dogmatic method, too often applied in matters of philosophy, we must substitute the empirical or critical method - the method which the special sciences have proved so fruitful in their own domain. It is not the province of metaphysics to dictate to reality what it must be, but to discover its fundamental meaning. It is only when pursued in this spirit that metaphysics can take rank as a science, and, at least in its ideal, as the science of sciences. (1916: xvii)

Unlike in his early paper "Philosophic Tolerance" Boodin now sharply distinguishes between metaphysics and art. "In art," he maintains, "the selective activity is for the sake of permanent objects of enjoyment; in metaphysics, for the sake of understanding. Metaphysics is science, not art." (1916: xxi). Accordingly, metaphysics "implies, and furnishes the inspirations of, the special sciences" (ibid.). It "deals with the common and overlapping problems, left over by the special sciences" and it "must ever be present as a regulative ideal in all our search for truth" (ibid.).

Just as in "Pragmatic Realism," Boodin defines "being" in terms of energetics (cf. Boodin 1916: 3). In his view, energy is to be conceived of as an "Urstoff" (1916: 15). James's account of experience as "self-sufficient" (ibid.) is therefore wrongheaded. ${ }^{18}$ For Boodin, " our experience, at any rate, seems to depend in many ways upon an extra-experiential constitution" (1916: 16). Consequently, "we cannot resolve reality, whether conscious or unconscious, into bundles of perception, or into experience of any form, altogether. We must interpolate, somehow, realities which are not immediate experience." (1916: 20).

It is at this very point that, according to Boodin, pragmatism and realism coincide. Chapter III of A Realistic Universe is titled "Pragmatic Energism." By "energism" Boodin understands a thoroughly realistic interpretation of the concept of energy. Energy is, on this account, not to be thought of as an unknowable Kantian thing-in-itself (cf. Boodin 1916: 33). Rather, it is the driving force of natural processes and, as such, by all means knowable. The pragmatic element primarily pertains to the dynamic aspect of energetically conceived reality. Boodin therefore declares: "We must hold to the pragmatic postulate that energy is what it does." (Ibid.). For example, physical properties such as weight, for Boodin, do not exist in the abstract. Nor do physical things have properties in themselves. Rather, things possess properties "only within a system, and such properties vary with the conditions which determine the system" (1916: 35). Thus the weight of a body varies at different points of the surface of the earth; it is, in other words, a function of the attraction of the earth. More generally, "[p]roperties have no meaning for science, except as energy determinations, characteristics within energy systems" (ibid.: 36). Accordingly, relativity is "a fundamental characteristic of energy 
systems" (ibid.: 50). Alluding to Einstein's theory of relativity (without mentioning Einstein himself) Boodin points out that "[w]e know of no absolute position in space or absolute system of relations" (ibid.) and that "[o]ur standards of measurement, whether of energy, time, or space, are all alike pragmatic" (ibid.).

From all this, however, it does not follow that things are "created or 'faked"' (1916: 70). Rather, "[ $t]$ he thing must suggest an own center of energy" (ibid.). It is for this reason that Boodin assumes that things cannot be infinitely divisible. A certain form of atomism recommends itself. Boodin writes:

Do we come to a limit in our division where we have to deal with a final natural unity? We do for practical reasons at least. The molecule, which, thanks to Perrin, has now been definitely identified and measured, seems like a distinct stopping place, if we would preserve the character of the compound. And in recent years interesting experiments have been made by Rutherford and others to prove the real existence of the atom. These results cannot be ruled out by any a priori theory as regards infinite divisibility. (Boodin 1916: 71)

Ontologically, atoms, according to Boodin, have the status of energy centers: they must be conceived as "more or less stable dynamic clusters within dynamic systems" (ibid.: 83). Yet it is important to emphasize that this does not imply a "relapse" to materialism. Just as in the case of Ostwald (cf. Ostwald 1895) energetics (or "energism") qualifies as an alternative to the materialistic point of view. The energy concept simply proves to be more general than the concept of matter. In Boodin's words:

The conception of energy has gradually supplanted the conception of matter as a universal ideal of description. Matter is applicable only within a limited field. It is not applicable, for example, to electricity; while energy with its equivalences of transformation can be made to cover the whole extent of process, material and immaterial, physical and psychological. (Boodin 1916: 389) ${ }^{19}$

41 Let us now make a time jump to 1934. This was the year when Boodin's "Functional Realism" appeared in The Philosophical Review. The principle aim of this paper was to establish "functional" realism as a "third way" within the realist movement. Remember that American realism had emerged in two forms, "new" and "critical" realism. In the paper, Boodin repudiates both of these two forms. Right at the beginning he makes the following critical statement:

Naïve [i.e., new; M.N] and critical realism have one fundamental assumption in common. They both assume that to say that substances and qualities exist independently of the environment has a meaning. They make, at the outset, a bifurcation of thing and environment as though they were only externally related. They postulate things in themselves with properties in themselves. This postulate rests on an antiquated science. (Boodin 1934: 147-8)

As a programmatic characterization, this diagnosis is false. To be sure, the bifurcation of thing and environment figured prominently within the framework of new realism. ${ }^{20}$ However, from the standpoint of critical realism, there is no such bifurcation. It was particularly Sellars who, in his Evolutionary Naturalism, insisted upon the interrelatedness of physical objects, perceiving organisms and their environment. ${ }^{21}$ Furthermore, the entire functional idea is obviously prefigured in Sellars's writings. For him,

[p]hysical things possess dynamic capacities. They are centers of produced change. [...] Real processes occur all around us of prime importance for our welfare. The physical world is the seat of activities whose drift and course it is to our advantage to learn. (Sellars 1922: 127)

Much the same is asserted by Boodin when we writes: 
As opposed to the assumption of things in themselves with properties in themselves, functional realism holds in common with present science that the bifurcation of thing and environment is vicious, that things exist only in fields, in mutuality with other things, and that they have properties only in their dynamic interrelations. (Boodin 1934: 148)

In order to prevent misunderstandings let me emphasize that I do not claim that Boodin simply took over one of Sellars's most prominent ideas. The functional aspect as such can already be found in A Realistic Universe, i.e., six years before Sellars made his claim. In fact, the actual problem is to understand why Boodin thinks his own approach needs to be so sharply distinguished from critical realism. Moreover, one might wonder how 'functional' realism is related to pragmatism. It is these questions that I finally want to briefly address.

\section{Lost in the Isms?}

To begin with, when Boodin published his "Functional Realism" the philosophical context had significantly changed as compared to the time when Truth and Reality and A Realistic Universe came out. Idealism had almost disappeared from the scene, and the realist camp had developed into a more diversified form. Moreover, classical pragmatism had shifted to so-called neo-pragmatism, especially with the appearance of C. I. Lewis's Mind and the World Order in 1929 (cf. Misak 2013, ch. 10).

Now the striking thing about Boodin's critique of critical realism is that it is far too selective. His main target in "Functional Realism" is George Santayana's Skepticism and Animal Faith from 1923 (see Boodin 1934: 149-57). However, as Sellars repeatedly stressed (see, for example, Sellars 1924: 383), there existed two "wings" within the critical realist movement: a metaphysical ("essentialist") wing, primarily represented by the work of Santayana, and an empirical ("naturalist") wing, primarily represented by Sellars's own contributions. Would Boodin have focused on Sellars's account of critical realism, his critique, I maintain, would not have worked. Thus, if at all, then functional realism stood in sharp contrast to the essentialist version of critical realism.

Regarding pragmatism, it is interesting to note that Boodin does not make any mention of it in "Functional Realism." To be sure, at two places he casually refers to James (1934: 161) and to Dewey (1934: 171). But the major purpose of the paper is obviously to establish functional realism as an autonomous position. On the other hand, the realist aspect as such is undermined, or at least downplayed, by statements such as: "Things are the result of interest and conceptual interpretation." (Ibid.: 151). It is quite hard to understand how this should motivate a realist position. All in all, one might suspect that Boodin eventually got lost in the -isms.

However, a more charitable reading would account for the fact that the systematical and historical relation of pragmatism and realism, as it were, provoked the sort of eclectic fusion to be found in Boodin's later work. In some cases, even nowadays it is unclear, where exactly pragmatism and realism part their ways (see in this connection, for example, the writings of the late Hilary Putnam). At any rate, Boodin's contributions to the complex discussion of realism, pragmatism, and their mutual relationship are worth reconsidering. 


\section{BIBLIOGRAPHY}

BooDIN John Elof, (1908), “Philosophic Tolerance. A Winter Revery,” The Monist, 18, 298-306.

BooDin John Elof, (1909), “What Pragmatism Is and Is not," Journal of Philosophy, Psychology and Scientific Methods, 23, 627-35.

BoodiN John Elof, (1910), “Pragmatic Realism,” The Monist, 20, 602-14.

Boodin John Elof, (1911a), “From Protagoras to William James,” The Monist, 21, 73-91.

Boodin John Elof, (1911b), Truth and Reality: An Introduction to the Theory of Knowledge, New York, Macmillan.

BooDIN John Elof, (1916), A Realistic Universe: An Introduction to Metaphysics, New York, Macmillan. BooDiN John Elof, (1930), “Nature and Reason," in Contemporary American Philosophy: Personal Statements, vol. 1, edited by George P. Adams \& William Pepperell Montague, New York, Macmillan,135-66.

BoodiN John Elof, (1934), “Functional Realism,” The Philosophical Review, 43, 147-78.

Boodin John Elof, (1939), The Social Mind: Foundations of Social Philosophy, New York, Macmillan.

CARUS Paul, (1908), "Pragmatism," The Monist, 18, 321-62.

DelTETE Robert J., (1983), “The Energetics Controversy in Late Nineteenth Century Germany: Helm, Ostwald, and Their Critics," PhD diss., Yale University.

DEWEY John, (1905), “The Realism of Pragmatism," Journal of Philosophy, Psychology and Scientific Methods, 2, 324-7.

DRAKE Durant, LOVEJOY Arthur O., PRATT James B., ROGERS Arthur K., SANTAYANA George, WOOD SELLARS Roy \& Charles A. STRONG (eds), (1920), Essays in Critical Realism: A Co-Operative Study in the Problem of Knowledge, London, Macmillan.

EDITORIAL COMMENT TO BOODIN, (1908), The Monist, 18, 306.

EDITORIAL COMMENT TO BOODIN, (1910), The Monist, 20, 614-5.

HOLT Edwin B., MARVIN Walter T., MONTAGUE William P., PERRY Ralph B., PITKIN Walter B. \& Edward G. SPAULDING (eds), (1910), "The Program and First Platform of Six Realists," The Journal of Philosophy, Psychology and Scientific Methods, 7, 393-401.

HOLT Edwin B., MARVIN Walter T., MONTAGUE William P., PERRY Ralph B., PITKIN Walter B. \& Edward G. SPAULDING (eds), (1912), The New Realism: Cooperative Studies in Philosophy, New York, Macmillan. JAMES William, (1904), “Does Consciousness Exist?," Journal of Philosophy, Psychology and Scientific Methods, 1, 477-91.

JAMES William, (2017 [1907]), Pragmatism: A New Name for Some Old Ways of Thinking, Whithorn, Anodos.

JAMES William, (1909), A Pluralistic Universe. Hibbert Lectures at Manchester College on the Present Situation in Philosophy, New York, Logmans, Green. 
JAMES William, (1912), Essays in Radical Empiricism, New York, Longmans, Green.

KUKLICK Buce, (2001), A History of Philosophy in America, 1720-2000, Oxford, Clarendon.

KUKLICK Bruce, (2017), “Who Owns Pragmatism?,” Modern Intellectual History, 14, 565-83.

LEWIS Clarence I., (1929), Mind and the World Order: Outline of Theory of Knowledge, New York, Scribner's.

Lovejoy Arthur O., (1908), “The Thirteen Pragmatisms," Journal of Philosophy, Psychology and Scientific Methods, 5, 5-12.

LOVEJoy Arthur O., (1920), "Pragmatism Versus the Pragmatist," in Durant Drake, Arthur O. Lovejoy, James B. Pratt, Arthur K. Rogers, George Santayana, Roy Wood Sellars, \& Charles A. Strong (eds), Essays in Critical Realism: A Co-Operative Study in the Problem of Knowledge, London, Macmillan, 35-81.

MISAK Cheryl, (2013), The American Pragmatists, Oxford, Oxford University Press.

NELSON Charles H., (1984), “John Elof Boodin. Philosopher-Poet,” Swedish-American Historical Quarterly, 35, 124-50.

NEUBER Matthias, (2002), "Physics Without Pictures? The Ostwald-Boltzmann Controvery, and Mach's (Unnoticed) Middle-Way," in Michael Heidelberger \& Friedrich Stadler (eds), History of Philosophy of Science: New Trends and Perspectives, Dordrecht, Kluwer, 185-98.

OSTWALD Wilhelm, (1895), "Die Überwindung des wissenschaftlichen Materialismus,"

Verhandlungen der Gesellschaft deutscher Naturforscher und Ärzte, 1895, 155-68.

PEIRCE Charles S., (1905), "What Pragmatism Is,” The Monist, 15, 161-81.

PERRY Ralph Barton, (1912), Present Philosophical Tendencies: A Critical Survey of Naturalism, Idealism, Pragmatism, and Realism, Together With a Synopsis of the Philosophy of William James, New York, Longmans, Green.

PIHLSTRÖM Sami, (2010), "Nordic Pragmatism," European Journal of Pragmatism and American Philosophy, 2 (1), 108-20. Online: [journals.openedition.org/ejpap/945].

RANDALL John H., (1966), “Josiah Royce and American Idealism,” The Journal of Philosophy, 63, 57-83. ROYCE Josiah, (1900), The World and the Individual, First Series, New York, Macmillan.

SANTAYANA George, (1923), Skepticism and Animal Faith: Introduction to a System of Philosophy, New York, Dover.

SELLARS Roy Wood, (1908), "Critical Realism and the Time Problem," The Journal of Philosophy, Psychology and Scientific Methods, 5, 542-48.

SELLARS Roy Wood, (1916), Critical Realism: A Study of the Nature and Conditions of Knowledge, Chicago and New York, Rand McNally and Company.

SELLARS Roy Wood, (1922), Evolutionary Naturalism, Chicago, Open Court.

SELLARs Roy Wood, (1924), "Critical Realism and Its Critics," The Philosophical Review, 33, 379-97.

SELLARS Roy Wood, (1969), Reflections on American Philosophy from Within, Notre Dame, University of Notre Dame Press.

SHOOK John R., (1998), Pragmatism: An Annotated Bibliography, 1898-1940, Amsterdam, Rodopi. SLATER Michael R., (2011), “William James's Pluralism,” Review of Metaphysics, 65, 63-99. 
SLURINK Pouwel, (1996), "Back to Roy Wood Sellars: Why His Evolutionary Naturalism Is Still

Worthwile," Journal of the History of Philosophy, 34, 425-49.

sUZUKI Daisetz T., (1962), The Essentials of Zen Buddhism, New York, Greenwood Press.

WERKMEISTER William H., (1949), A History of Philosophical Ideas in America, Ney York, The Ronald

Press Company.

\section{NOTES}

1. For a comprehensive account of Boodin's life and work, see Nelson 1984 (on which I primarily draw here).

2. Werkmeister writes in this connection: "James was instrumental in preparing the way for realism. His personality as well as his philosophy had a marked and far-reaching influence upon a whole generation of American thinkers. James's books and articles published during the first decade of the twentieth century contain many realistic tendencies, and not less than seven of the leading realists - Drake, Montague, Perry, Pratt, Santayana, Sellars, and Strong - have repeatedly stated that their philosophical position was determined by James." (Werkmeister 1949: 371).

3. It is, by the way, quite difficult to determine what the distinctive characteristic of "European" pragmatism could be. Maybe the present volume helps to come closer to an answer to that question.

4. See Randall 1966. As, on the other hand, Werkmeister makes it particularly clear, Royce's variant of idealism was by no means the only idealistic statement at that time. Rather, idealism was a multifaceted movement. There were many kinds of idealism (and many pre-eminent idealists) in the United States around the 1890s, such as the Hegelian-inspired St. Louis Group around Henry C. Brokmeyer and William Harris, the "personalisms" of Borden Parker Bowne and George H. Howison and several explicitly religious versions of idealism. For further details, see Werkmeister 1949, chapters 5-9.

5. Holt, Montague and Perry all had studied under Royce at Harvard. See, in this connection, Kuklick (2001: 202-3). However, James's influence upon them was obviously the trend-setting factor. As, again, Werkmeister points out: "It is evident [...] that James, who never regarded himself as a realist, was the intellectual godfather of the realistic movement in America. It was he who encouraged the younger men in the field to break with tradition, to explore new possibilities and new horizons." (Werkmeister 1949: 371).

6. For the latter, see the insightful reconstruction in Slater 2011.

7. It should be noted that the very term "critical realism" was used by Sellars as early as 1908 (see Sellars 1908) and that he already in 1916 published a book explicitly titled Critical Realism (see Sellars 1916).

8. Furthermore, they demarcated their understanding of the term "critical" from the Kantian one by declaring that "the word "critical' has no reference to the Kantian philosophy, which should not be allowed to monopolize that excellent adjective." (Drake et al. 1920: vi).

9. See, in this connection, already Lovejoy 1908; further, for an evaluation, Kuklick 2017.

10. When he wrote the 1908 paper, Boodin already had a professorship at the University of Kansas.

11. See, in this connection, his extended critique of James's variant of pragmatism in Carus 1908. The concluding remarks of this paper are sufficiently explicit: "Personally, I have a decided liking for Professor James, and I am sure that in expressing it I voice the opinion of many. I have met him repeatedly and have felt the sympathetic charm of his personality. I wish him all possible success and the honor of merited renown. I hope that for the rest of his life he will remain as buoyant and spirited as he has ever been, and will meet with unlimited recognition. But for all 
that I can not agree with or accept the philosophy of the great Harvard Professor, and I go so far as to look upon its wide acceptance as a symptom of the immaturity and naivite that obtains sometimes even in the professional circles of our universities. With all due respect for Professor James, for whose extraordinary and fine personality I cherish an unbounded admiration, I must confess that I would deem it a misfortune if his philosophy would ever exercise a determining and permanent influence upon the national life of our country." (Carus 1908: 361-2).

12. The following passages from James's 1907 lecture series might corroborate this diagnosis: "Pragmatism [...] asks its usual question. 'Grant an idea or belief to be true,' it says, 'what concrete difference will its being true make in anyone's actual life? How will the truth be realized?" (James 2017[ 1907]: 74). “Truth in science is what gives us the maximum possible sum of satisfaction, taste included, but consistency both with previous truth and with novel fact is always the most imperious claimant." (Ibid.: 80).

13. In James's words, the same message reads thus: “The 'absolutely' true, meaning what no farther experience will ever alter, is that ideal vanishing-point towards which we imagine that all our temporary truths will some day converge. It runs on all fours with the perfectly wise man, and with the absolutely complete experience." (James 2017 [1907]: 82).

14. In this case, too, an Editorial Comment was attached. In its opening paragraph the following is clarified: "Prof. John E. Boodin will be remembered by the readers of The Monist for his article 'Philosophic Tolerance' (April, 1908) in which he supported the pragmatism of Professor James. At that time the editor asked him to make a reply to comments on his views in the editorial article which appeared in the following issue [cf. Carus 1908; M.N.]. Professor Boodin has not made use of the invitation, but prefers to offer to the readers of The Monist an exposition of his views without reference to the controversy in question." (Editorial Comment to Boodin 1910: 614).

15. Editorial Comment to Boodin (1910: 615).

16. For a comprehensive reconstruction of the energetic world-view, see Deltete 1983.

17. In his Pragmatism, James explicitly states that „[t]ruth happens to an idea. It becomes true, is made true by events. Its verity is in fact an event, a process: the process namely of its verifying itself, its veri-fication." (James [1907] 2017: 74). According to Boodin, on the other hand, "[t]ruth is our version of reality. [...] It is nonsense to speak of an hypothesis, which is our meaning or attitude, as true previous to verification; but previous to verification there exist certain conditions, which make some hypotheses come true." (Boodin 1911b: 228). These latter conditions should be conceived of as - energetically definable - "truth-makers," which in James's theory wouldn't find any place because of their being postulated as existing previous to verification.

18. Boodin refers here implicitly to James's Essays in Radical Empiricism from 1912.

19. It should be noted that Ostwald - unlike Boodin - not only rejected materialism, but also atomism. For further details, see Ostwald 1895 and the reconstruction in Neuber 2002.

20. See, in this connection, especially Perry's account of "external relations" in Perry 1912.

21. See esp. Sellars (1922: 72-3) and the reconstruction in Slurink 1996. 


\section{ABSTRACTS}

This paper explores the philosophical approach of the Swedish-born thinker John Elof Boodin. It will be shown that Boodin's philosophical development ran through various stages, beginning with more or less "orthodox" pragmatism and ending with what he labeled "functional" realism. My principal thesis is that, in the last analysis, Boodin failed in establishing a stable systematic point of view. However, his philosophical development is worth considering in some detail because it nicely reflects the situation of a European-born philosopher in early-twentieth century America.

\section{AUTHOR}

\section{MATTHIAS NEUBER}

Universität Tübingen

matthias.neuber[at]uni-tuebingen.de 